\title{
DREAMzone: Educating Counselors and Human Service Professionals Working with Undocumented Students
}

\author{
Jesus Cisneros \\ University of Central Arkansas
}

Anna Lopez

New Mexico State University

\begin{abstract}
This article discusses the development and implementation of DREAMzone, an educational intervention designed to provide counselors and other human service professionals with awareness, knowledge, and skills for working with undocumented students. DREAMzone is driven by four learning objectives: (a) identify and deconstruct preconceptions of undocumented immigrants; (b) increase knowledge about laws and policies affecting the experiences of undocumented students; (c) engage in direct contact with undocumented students; and (d) acquire skills, practices, and resources for working with undocumented students. Program reflections are provided, including future directions for effectuating a systems level transformation within higher education.
\end{abstract}

Keywords: DREAMzone; Immigration; Counseling; Undocumented; Higher Education

Families immigrate to the United States each year for various reasons, among them the fundamental need to improve their lives (Cervantes, Mejia, \& Mena, 2010). Some of the main motivators include economic necessity (McGuire \& Martin, 2007) and violence (Bernard, 2009), as well as issues of family reunification in the United States (Donato \& Patterson, 2004; Gaytan, Carhill, \& Suarez-Orozco, 2007). As of 2013, approximately 41.3 million immigrants, including more than 11 million undocumented immigrants, were living in the United States (Zong \& Betalova, 2015). Of the undocumented group, about one million were under the age of 18 , and 4.4 million were under the age of 30 (Passel \& Lopez, 2012). 
A growing body of research has sought to understand the circumstances of undocumented immigrants who come to the United States as children (Gonzáles, 2010, 2011; Gonzáles \& Chavez, 2012; Gonzáles, Heredia, \& Negron-Gonzáles, 2015; Greenman \& Hall, 2013). Migrating at an early age typically implies that individuals have spent a significant part of their formative years in the United States, making them part of the 1.5 generation immigrant experience (Rumbaut, 2004). Those who arrive to the United States as children and enroll in the K-12 education system become incorporated into the nation through social relationships and public school experiences. However, as they reach adolescence and become aware of their undocumented status, they often feel cast out and forced to live in the world as "illegal" subjects (Gonzáles \& Chavez, 2012, p. 267). Legal exclusions constrain many mundane yet critical aspects of life and inculcate anxiety, fear, and stress (Gonzáles, Suárez-Orozco, \& Dedios-Sanguineti, 2013; Menjívar \& Abrego, 2012; Szkupinski Quiroga, Medina, \& Glick, 2014). Without access to state identification documents or driver's licenses, for example, undocumented immigrants risk detention, deportation, and family separation by driving to work or school, particularly within states that invest local police for non-federal immigration enforcement initiatives (Stuesse \& Coleman, 2014).

Systematic challenges additionally restrict undocumented immigrants' college access and persistence (Gonzáles, 2010; Pérez, Cortes, Ramos, \& Coronado, 2010; Suárez-Orozco, Yoshikawa, Teranishi, \& Suárez-Orozco, 2011). Although federal law does not forbid undocumented students from attending college, being undocumented usually implies that they are not eligible for most scholarships and do not qualify for any form of federal government-sponsored financial assistance (Pérez, Espinoza, Ramos, Coronado, \& Cortes, 2009). Several state laws and policies additionally disqualify undocumented immigrants from applying for in-state tuition status, state-based financial aid, or sometimes college admission altogether (Contreras, 2009; Flores, 2010; Gildersleeve, Rumann, \& Mondragon, 2010; Gonzáles, 2009, 2010; Martinez, 2014; Sáenz, Aguilar Rodríguez, Martínez, \& Romo, 2011). Without access to federal or state aid, undocumented immigrants face heavy financial burdens to enroll and persist in college.

The experiences of undocumented youth present layers of challenges for counselors and other human service professionals in the field of education. Varying factors related to undocumented immigrants' experiences often go unnoticed to practitioners unfamiliar with the process of immigration and the stigma of "illegality" (De Genova, 2002; Gonzáles \& Chavez, 2012; Menjívar \& Kanstroom, 2014). Though institutions play a key role in helping students locate resources necessary to achieve their educational goals, hostile and difficult institutional environments often prevent students from seeking out the support they need (Contreras, 2009; Diaz-Strong, Gomez, Luna-Duarte, \& Meiners, 2011; Jauregui \& Slate, 2010; Pérez \& Cortes, 2011; Teranishi, Suárez-Orozco, \& Suárez-Orozco, 2015). As a result, undocumented students are often left to deal with pervasive fear and uncertainty in the shadows of the institution (Gonzáles, 2010; Pérez et al., 2010; Suárez-Orozco et al., 2011; Teranishi et al., 2015).

Counselors and other human service professionals in education are uniquely positioned to intervene systemically through social advocacy and culturally relevant interventions aimed at reducing prejudice toward undocumented immigrants. Social advocacy interventions are particularly significant when human service professionals "become aware of external factors that act as barriers to an individual's development" and "when individuals or vulnerable groups lack access to needed services" (Lewis, Arnold, House, \& Toporek, 2002, p. 1). The need for counselors to develop the necessary competencies to work with undocumented students is supported by the Multicultural and Social Justice Counseling Competencies (MSJCC) developed and endorsed by the Association for Multicultural Counseling and Development (Ratts, Singh, Nassar-McMillan, Butler, \& McCullough, 2015). According to the MSJCC 
model, "privileged and marginalized counselors intervene with and on behalf of clients at the intrapersonal, interpersonal, institutional, community, public policy, and international/global levels" (Ratts et al., 2015, p. 11). Undocumented students are more likely to stay in school and feel less emotional distress when they are supported and when they are able to talk openly about the challenges associated with their immigrant experiences (Gonzáles et al., 2013). The purpose of this article is to introduce an educational program designed to provide counselors and other human service professionals in education with awareness, knowledge, and skills for working with undocumented students. Increasing human service professionals' awareness and understanding of the experiences and needs of undocumented immigrants is necessary for building culturally responsive methods and systems that reduce students' vulnerability to mental health challenges and increase their opportunities for educational attainment.

\section{Supporting Undocumented Students}

Researchers have generally suggested that counselors and other human service professionals in education need to focus on integrating undocumented students into the larger student body and encouraging them to establish support networks including student organizations (Gonzáles et al., 2015). Pérez (2010), for example, recommends that human service professionals focus on outreach and recruitment initiatives such as conferences for undocumented students and parents, where both groups can learn about the pathways to, and implications of, higher education. Other researchers suggest staying abreast of demographic shifts in higher education resultant from increased enrollment of undocumented students and state and federal policy changes (Canedo Sanchez, \& So, 2015). Currently, only 18 states have legislated that undocumented immigrants graduating from a state high school are eligible for in-state tuition: California, Colorado, Connecticut, Florida, Illinois, Kansas, Maryland, Minnesota, Nebraska, New Jersey, New Mexico, New York, Oklahoma, Rhode Island, Oregon, Texas, Utah and Washington. Additionally, only six states extend eligibility for state-funded financial aid: California, Minnesota, New Mexico, Oregon, Texas, and Washington (National Conference of State Legislators, 2015). It is recommended that counselors make this information and related resources readily available to all students, regardless of their immigration status, in order to help undocumented students identify and secure opportunities for higher education attainment (Pérez, 2010).

However, most important to the purpose of this article is the recommendation for institutionalized training on issues related to undocumented students (Chen, 2014; Gildersleeve \& Vigil, 2015; Oseguera, Flores, \& Burciaga, 2010; Pérez, 2010; Pérez \& Rodriguez, 2011; Pérez et al., 2010; Pérez et al., 2009; Suárez-Orozco et al., 2015). Over the last couple of years, a few institutions have begun to respond to the increasing visible presence of undocumented students on campus by developing programs and interventions that seek to increase practitioners' awareness, knowledge, and skills for working with undocumented students (e.g., AB 540 Ally Training, DREAMzone, UndocuAlly, UndocuPeers). Such interventions often work to deepen human service professionals' understanding of undocumented student experiences and how to best support undocumented students personally, socially, and professionally (Canedo Sanchez \& So, 2015).

The recommendation for institutionalized training is particularly significant, given the current sociopolitical context of immigration in the United States. The stance of attrition through enforcement in states like Arizona has manifested into a series of laws, restrictive in nature, that criminalize undocumented immigrants and convert mundane acts, like driving, into high-risk activities (Stuesse \& Coleman, 2014). Attrition through enforcement refers to the idea of creating an environment so hostile 
toward undocumented immigrants that undocumented immigrants will have no choice but to selfdeport. However, such measures have also had the effect of uprooting and separating families, atomizing communities, and bringing about the disintegration of social and economic support networks (Corazón de Tucson, 2012). Undocumented and mixed-status families often end up not reporting crimes to the police, not visiting physicians or hospitals even in emergency situations, and not sending their children to school (Lopez, 2011). The growing mistrust of public institutions resultant from the passage of these laws indicates that there is a need for counselors and other human service professionals in education to engage in social advocacy interventions that enable participants to reduce stigma and discrimination toward undocumented immigrants and mend their institution's relationship with the community.

The following section describes an educational program in Arizona that heeds scholars' calls for professional development trainings that prepare counselors and other human service professionals to work with undocumented students. The emergence of institutionalized support services for undocumented students across institutions of higher education provides possibilities for a systems level transformation that acknowledges the important role of human service professionals. These trainings not only provide the awareness, knowledge, and skills necessary for working with undocumented students, but they also deliver a clear message of inclusive excellence and highlight the importance of institutionalized safe spaces.

\section{DREAMzone}

Founded in 2012, DREAMzone is an educational intervention at Arizona State University designed to provide counselors and other human service professionals in education with awareness, knowledge, and skills for working with undocumented students. DREAMzone was created in an effort to acknowledge and address the unique challenges encountered by undocumented students and increase their educational attainment. Given the detrimental effects of the aggressive enforcement of immigration law in states like Arizona, DREAMzone seeks to reduce stigma and discrimination toward undocumented immigrants by promoting more culturally sensitive practices for responding to the presence and needs of undocumented students (Cadenas, Cisneros, Todd, \& Spanierman, 2016).

DREAMzone consists of 4-hour professional development workshops that are free of charge and open to the community. These workshops average between 15-30 participants per session and are facilitated by undocumented students and allies. Workshops are hosted by Arizona State University or are arranged by partnering educational institutions and organizations within the community. Though workshops target helping professionals in college settings, they are often also conducted off-campus and adjusted to accommodate the needs of K-12 professionals and teacher preparation programs (e.g., Teach for America). Consequently, the majority of participants work in educational settings. Participants either self-register or are mandated by their supervisors to attend as part of professional development training. To date, DREAMzone has trained over 2,000 participants and has been recognized at the local, state, and national level, including the Clinton Global Initiative University in 2013, for its innovative approach to addressing global challenges and societal needs.

DREAMzone is grounded by four learning objectives: (a) identify and deconstruct preconceptions of undocumented immigrants; (b) increase knowledge about laws and policies affecting the experiences of undocumented students; (c) engage in direct contact with undocumented students; and, (d) acquire skills, practices, and resources for working with undocumented students. The following section provides 
the pedagogical framework for implementing the program at other institutions and describes the learning objectives, as embedded within the program's curriculum.

\section{Pedagogical Framework}

Because counselors and other human service professionals in education are charged with providing services, intervening, and addressing the needs of undocumented students, it is incumbent on them to ensure that they have the insight, knowledge, and tools necessary for culturally responsive practice. For this reason, and in order to help sustain diverse and inclusive campuses, DREAMzone embedded the tripartite model of cultural competence within its curriculum (Sue et al., 1982). The tripartite model emphasizes the importance of integrating awareness, knowledge, and skills for working with others who are culturally different from one's self. Such an approach seeks to move participants to a level where they are able to engage in critical reflective thinking and make judgments about situations that may hinder students' success. Because this model has become an integral part of multicultural counseling training (Ridley, Mendoza, \& Kanitz, 1994), the following sections describe our positionalities as DREAMzone facilitators and the integration of the tripartite model in our work with counselors and other human service professionals in education.

I, Jesus Cisneros, am one of the founding members of DREAMzone. I identify as a naturalized citizen and queer Latino. I migrated to the United States from Mexico at the age of six and have been organizing for immigrant rights since 2012. I, Anna Lopez, identify as a naturalized citizen and heterosexual Latina. I migrated to the United States from Mexico at the age of five and work with migrant clients in my counseling practice. Our positionalities as 1.5-generation immigrants inform our involvement as facilitators within DREAMzone. We approach this work with awareness that our privileges, in terms of citizenship, represent what may be significant blind spots in our ability to advocate with and for undocumented students. For this reason, DREAMzone prioritizes the involvement of undocumented students as facilitators and invests in their growth and development by encouraging them to lead.

Awareness. The first element in the tripartite model is awareness and aligns with the first learning objective of identifying and deconstructing preconceptions of undocumented immigrants. Awareness consists of the attitudes, values, beliefs, and assumptions that shape our understanding of individuals who are culturally different from us. Being self-aware and understanding the impact that our upbringing, life experiences, and cultural worldview have on our perceptions and interpersonal interactions is central to achieving multicultural awareness. For individuals who have inaccurate, incomplete, or biased knowledge, that information base must be corrected or completed before multicultural development can proceed (Sue et al., 1982). For this reason, DREAMzone facilitators begin by challenging participants to assess what they "know" about undocumented immigrants and identify stereotypes, biases, or culturally based assumptions. To facilitate this process, facilitators conduct an activity where participants have the opportunity to think about and write down all the messages they have received about undocumented immigrants. Participants are prompted to particularly consider the messages that they have received from preeminent sources of information, such as family, friends, colleagues, leaders, and media, and how these messages have shaped their values, beliefs, and worldviews regarding undocumented immigrants.

Participants are then asked to share the messages they wrote and collectively organize these messages according to source (e.g., family, friends, colleagues, leaders, and media). This exercise illustrates the barrage of messages individuals receive about undocumented immigrants on a daily basis and enables participants to compare, contrast, and analyze the dominant perspectives observed within and across 
the various sources of messaging. The facilitator uses the following guiding questions to incite discussion:

1. What do you see?

2. What, if anything, stands out to you? Why?

3. Where do these perceptions come from? How are these perceptions developed?

4. How do these messages impact the way we perceive undocumented immigrants?

5. Why is it important to interrogate the messages we receive?

Through discussion, participants are pushed to explore how their knowledge of undocumented immigrants is justified for them. They explore whether sensory evidence, testimonial evidence, intuition, or some other means provides justification for the knowledge they possess. Facilitators explain that to be multiculturally competent, individuals must be open to challenging any misinformation they have obtained and unlearning any flawed assumptions and beliefs (Sue et al., 1982). For this reason, upon exploring the range of messages observed, facilitators provide counternarratives based on research and reports that help dispel some of the most common myths and stereotypes about undocumented immigrants (Table 1).

\begin{tabular}{|l|l|}
\hline $\begin{array}{l}\text { Table 1 } \\
\text { Counternarrative Research and Reports }\end{array}$ \\
\hline Myths & Facts \\
\hline $\begin{array}{l}\text { They are all } \\
\text { Mexican }\end{array}$ & Mexicans make up only 52\% of all undocumented immigrants (Passel \& Cohn, 2016). \\
\hline $\begin{array}{l}\text { They are all } \\
\text { Latinx }\end{array}$ & $\begin{array}{l}\text { About 7.8 million unauthorized immigrants (71\%) were born in Mexico and other } \\
\text { Central American countries; } 1.5 \text { million (14\%) were from Asia; 690,000 (6\%) from } \\
\text { South America; 423,000 (4\%) from Europe, Canada, or Oceania; 342,000 (3\%) from } \\
\text { Africa; and 260,000 (2\%) from the Caribbean (Zong \& Balatova, 2016). }\end{array}$ \\
\hline $\begin{array}{l}\text { They entered } \\
\text { illegally }\end{array}$ & $\begin{array}{l}\text { As much as 45\% of the total undocumented immigrant population entered the } \\
\text { country legally with nonimmigrant visas and border crossing cards (Pew Hispanic } \\
\text { Research Center, 2006). }\end{array}$ \\
\hline $\begin{array}{l}\text { They don't pay } \\
\text { taxes }\end{array}$ & $\begin{array}{l}\text { Undocumented immigrants contribute nearly \$12 billion each year in income, } \\
\text { property, sales, and excise taxes (Gee, Gardner, \& Wiehe, 2016). They add value to } \\
\text { the United States economy not only as taxpayers, but also as workers, consumers, } \\
\text { and entrepreneurs (Immigration Policy Center, 2011). }\end{array}$ \\
\hline $\begin{array}{l}\text { They exploit the } \\
\text { welfare system }\end{array}$ & $\begin{array}{l}\text { Undocumented immigrants do not qualify for welfare, food stamps, Medicaid, and } \\
\text { most other public benefits as a result of the Personal Responsibility and Work } \\
\text { Opportunity Reconciliation Act of 1996 (PRWORA). }\end{array}$ \\
\hline $\begin{array}{l}\text { They take } \\
\text { American jobs }\end{array}$ & $\begin{array}{l}\text { The benefits of immigration include economic growth, innovation, and } \\
\text { entrepreneurship, with little to no negative effects on the overall wages or } \\
\text { employment of native-born workers in the long term (Blau \& Mackie, 2016). }\end{array}$ \\
\hline $\begin{array}{l}\text { They take seats } \\
\text { away from } \\
\text { American } \\
\text { college } \\
\text { students }\end{array}$ & $\begin{array}{l}\text { No university has a special or unique admissions process for undocumented students. } \\
\text { Undocumented students must earn their admission to institutions of higher education } \\
\text { through their own merits, just like every other student (Canedo Sanchez \& So, 2015). }\end{array}$ \\
\hline
\end{tabular}

The process of dispelling myths is intended to enable participants to engage in the prejudice reduction process with an open mind and a more clear understanding of their thoughts, perspectives, knowledge, and feelings regarding undocumented immigrants. 
Knowledge. The second element of the tripartite model is knowledge and aligns with the second learning objective of increasing participants' knowledge about federal and state laws and policies affecting the experiences of undocumented students. This component specifically focuses on background information and content knowledge. Such knowledge helps participants contextualize what they observe, deepen their understanding, and enhance their ability to work with undocumented students by raising their own awareness of the diverse and complex factors that need to be considered (Sue et al., 1982). To facilitate this process, DREAMzone facilitators review terminology critical to participants' understanding of the intersection of immigration and education in the United States (e.g., undocumented, DACAmented, DREAMer, out-of-status, overstay, alien, illegal). Facilitators describe how each year nearly 80,000 undocumented children turn 18 , and an estimated 65,000 are expected to graduate from high school (Gonzalez, 2009). Of this group, 5-10\% will enroll in a college or university, and 1\% will graduate (Contreras, 2009; Passel, 2003; Russell, 2011). The purpose of this section is to provide a foundational knowledge base from which to draw upon as participants go over existing federal and state laws, policies, and rulings affecting undocumented students. Federal and state laws, policies, and rulings are discussed as being interconnected and interrelated within the current sociopolitical context of immigration in the United States (Table 2).

Facilitators help contextualize undocumented students' experiences by highlighting the opportunities and barriers to higher education access, particularly within the state of Arizona. They also describe the landscape of higher education for undocumented students across different states, and compare and contrast differing educational contexts based on the impact of laws, policies, and rulings. For example, facilitators provide a list of the states that currently provide in-state tuition rates for undocumented students and the states that additionally allow for state-based financial aid (National Conference of State Legislators, 2015). Facilitators also list states that take a restrictive approach toward undocumented students with regard to in-state tuition, state-based financial aid, and college admissions (e.g., Georgia, Alabama, South Carolina, Arizona, Indiana). Following this presentation, participants are able to identify states with undocu-friendly, undocu-hostile, or unstipulated stances based on the spirit of their laws and the nature of their impact on undocumented students. Participants are also able to examine the limitations of DACA and the uneven benefits and privileges provided for qualifying youth across states, particularly in regard to higher education access.

\begin{tabular}{|l|l|}
\hline $\begin{array}{l}\text { Table } 2 \\
\text { Federal and State Laws, Policies, and Rulings }\end{array}$ \\
\hline Federal & Description \\
\hline Plyler v. Doe (1982) & $\begin{array}{l}\text { In Plyler v. Doe (1982), the Supreme Court issued that states cannot } \\
\text { constitutionally deny students a free public K-12 education based on their } \\
\text { immigration status. }\end{array}$ \\
\hline $\begin{array}{l}\text { Illegal Immigration } \\
\text { Reform and Immigrant } \\
\text { (IIRIRA) of 1996 }\end{array}$ & $\begin{array}{l}\text { IIRIRA prohibits states from providing any higher education benefit based } \\
\text { on residency to undocumented immigrants unless they provide the same } \\
\text { benefit to United States citizens in the same circumstances, regardless of } \\
\text { their residence. }\end{array}$ \\
\hline $\begin{array}{l}\text { Personal Responsibility } \\
\text { and Work Opportunity } \\
\text { Reconciliation Act } \\
\text { (PRWORA) of } 1996\end{array}$ & $\begin{array}{l}\text { PRWOA states that undocumented immigrants are barred from receiving } \\
\text { any form of federal benefits for which payments or assistance are } \\
\text { provided by an agency of the United States or by appropriated funds of } \\
\text { the United States. }\end{array}$ \\
\hline
\end{tabular}




\begin{tabular}{|c|c|}
\hline \multicolumn{2}{|c|}{$\begin{array}{l}\text { Table } 2 \text { (continued) } \\
\text { Federal and State Laws, Policies, and Rulings }\end{array}$} \\
\hline Federal & Description \\
\hline $\begin{array}{l}\text { Development, Relief, } \\
\text { and Education for Alien } \\
\text { Minors (DREAM) Act }\end{array}$ & $\begin{array}{l}\text { The DREAM Act is a narrowly tailored bill that would allow eligible } \\
\text { undocumented youth to legalize their status in the United States if they } \\
\text { attend college or join the military. Since 2001, the DREAM Act has } \\
\text { undergone numerous revisions and has been reintroduced and defeated } \\
\text { in every Congress. }\end{array}$ \\
\hline $\begin{array}{l}\text { Deferred Action for } \\
\text { Childhood Arrivals } \\
\text { (DACA) }\end{array}$ & $\begin{array}{l}\text { DACA is an executive action that provides an opportunity for a qualified } \\
\text { segment of the undocumented immigrant population to receive a } \\
\text { renewable work permit and temporary reprieve from deportation. }\end{array}$ \\
\hline $\begin{array}{l}\text { Deferred Action for } \\
\text { Parents of Americans } \\
\text { and Lawful Permanent } \\
\text { Residents (DAPA) }\end{array}$ & $\begin{array}{l}\text { DAPA is an executive action allowing parents of United States citizens and } \\
\text { lawful permanent residents to request deferred action and employment } \\
\text { authorization. Due to a temporary injunction, this initiative has not yet } \\
\text { been implemented. }\end{array}$ \\
\hline State of Arizona & Description \\
\hline Proposition 300 & $\begin{array}{l}\text { Proposition } 300 \text { states that undocumented students are not eligible for } \\
\text { in-state tuition status or financial aid that is funded or subsidized by state } \\
\text { monies. }\end{array}$ \\
\hline Arizona House Bill 2008 & $\begin{array}{l}\text { HB } 2008 \text { requires applicants for public assistance from the state to prove } \\
\text { their legal status, and requires Arizona state agencies to report the names } \\
\text { of any undocumented immigrant applicants to the federal government. } \\
\text { Further, it establishes criminal penalties for government employees who } \\
\text { fail to report. }\end{array}$ \\
\hline $\begin{array}{l}\text { Arizona Senate Bill } \\
1070\end{array}$ & $\begin{array}{l}\text { SB } 1070 \text { requires reasonable attempt by police to determine the } \\
\text { immigration status of a person during any legitimate contact if reasonable } \\
\text { suspicion exists that the person is unlawfully present in the United States. }\end{array}$ \\
\hline $\begin{array}{l}\text { Arizona Dream Act } \\
\text { Coalition et al. v. } \\
\text { Brewer (2015) }\end{array}$ & $\begin{array}{l}\text { Arizona Dream Act Coalition et al. v. Brewer (2015) affirmed a lower } \\
\text { court's ruling that permanently blocks Arizona from denying driver's } \\
\text { licenses to immigrants who have been granted DACA. }\end{array}$ \\
\hline $\begin{array}{l}\text { State of Arizona } v . \\
\text { Maricopa County } \\
\text { Community College } \\
\text { District Board (2015) }\end{array}$ & $\begin{array}{l}\text { In State of Arizona v. Maricopa County Community College District Board } \\
\text { (2015), the superior court affirmed that a recipient of DACA who meets } \\
\text { Arizona law residency requirements is eligible for resident tuition. }\end{array}$ \\
\hline
\end{tabular}

Skills. The third component of the tripartite model is skills and aligns with the learning objectives of engaging in direct contact and acquiring skills, practices, and resources for working with undocumented students. Central to developing multicultural skills is the ability to communicate across cultural differences and understand how culture influences mundane aspects of everyday life. For this reason, a panel of undocumented students is invited to share their stories and describe their experiences navigating higher education. Panelists are members of on-campus and community-based immigrant rights organizations that collaborate with DREAMzone to embed community perspectives. In their stories, panelists discuss the transition from high school to college and the difficulty in obtaining competent assistance from helping professionals. Given the relative invisibility of their immigration status and the anti-immigrant sentiment experienced across the state, panelists describe their experiences as well as mental health issues pertaining to living in the shadows (Chávez, 1997). This form of direct contact is intended to provide participants with opportunities for self-reflection, empathy development, and growth toward cultural competence. 
The skills component also addresses participants' ability to form rapport with undocumented students and implement culturally responsive interventions (Sue et al., 1982). For this reason, facilitators encourage participants to openly dialogue with panelists and think about the ways their own department units can address the needs of undocumented students within existing programs, services, and outreach initiatives. Because the ability to develop appropriate skills is dependent on the ability to apply the awareness and knowledge previously obtained, participants are divided into small groups and led by panelists to identify ways in which institutional policy and practice could be made more undocufriendly. Specifically, participants are asked to think about ways in which they could increase students' opportunities to ask for help. Some guiding questions include:

1. Given the context of immigration and education policy in the state, what areas within the institution are creating barriers or opportunities for undocumented students?

2. How can divisions and functional units at the institution be more responsive to the needs of undocumented students?

3. How can you advocate with and for undocumented students within the scope of your position?

4. How can you create alternative processes that will provide equitable opportunities for undocumented students?

Following the small group discussions, participants are given the space to share their proposals for making their campus more undocu-friendly. Facilitators emphasize that ally work must be performed in collaboration with undocumented students in order to empower those most directly affected to lead (Ratts et al., 2015). The role of counselors and human service professionals should be to support the personal growth and development of undocumented students. For this reason, participants are encouraged to develop a coordinated outreach plan with immigrant youth-led organizations, advocacy groups, and other community-based organizations in order to collaborate, share resources, and increase the visibility of available supports.

At the conclusion of the training, participants are asked to identify and write down one immediate action they will take to improve undocumented students' experiences on campus. Participants then sign an undocu-ally agreement and receive a DREAMzone placard. The undocu-ally agreement identifies undocu-friendly practices that participants can engage in to negotiate solutions to the barriers and challenges that undocumented students face (Table 3 ). The placard serves as a visible symbol of support for undocumented students that can be posted on the walls or doors of public spaces. Together, the undocu-ally agreement and the placard formalize a personal commitment to improving undocumented students' experiences on campus.

\section{Table 3}

Undocu-Friendly Practices

1. Publicly demonstrate support for undocumented students

2. Issue an institutional statement that clearly articulates its support of undocumented students

3. Attend events pertaining to undocumented students

4. Display status-friendly materials (e.g., art, books, magazines)

5. Practice culturally sensitive language

6. Interrupt offensive jokes or language

7. Develop an undocumented student resource guide or brochure

8. Post undocumented student resources on the institutional Web site

9. Establish alternative legal forms of employment, internship, or research opportunities for undocumented students by providing payment via stipends or as independent contractors

10. Do not release immigration status or related information in confidential student records, without permission from a student, to federal agencies or other parties without a judicial warrant, a subpoena, a court order, or as otherwise required by law 


\section{Facilitator Reflections: Birth and Evolution of the Program}

Prior to DACA, Arizona had been impacted by a series of laws (e.g., Proposition 300, HB 2008, SB 1070) and popular anti-immigrant discourses that limited public employees' ability to outwardly support undocumented students within the scope of their positions. Consequently, a group of students, professional staff, faculty, and community experts came together to brainstorm knowledge mobilization efforts that would systematically support practitioners' work with undocumented students across all areas of higher education. The School of Transborder Studies at Arizona State University initiated the effort in response to the dwindling enrollment numbers of undocumented students, despite their significant share of the state's K-12 population. With the announcement of DACA in 2012, which stipulated educational attainment as a condition for eligibility, this work became even more prevalent as practitioners became increasingly aware of the implications of DACA for undocumented students.

Under the auspices of the student organizations we represented, those of us who were students within the collaborative organized an event called The DREAM: The Whole Story, which generated over 200 participants from across the university and the greater community. During this event, we listened to various stakeholders across different levels of leadership and undocumented students who shared their experiences of the campus culture. This conversation illustrated the need amongst practitioners to dialogue about issues most relevant to working with undocumented students. Given the politicization of education within the context of immigration, participants described how there was often no space made available to ask questions, interrogate processes, or incur professional development directly relevant to working with undocumented students. Many perceived the topic to be political and described the difficult environments on campus that prevented undocumented students from asking for help. Our collaborative developed the curriculum for DREAMzone based on these initial conversations and the expressed need for accessible and empirical information that reduced prejudice and informed everyday practice.

Following the announcement of DACA, however, as the animus against DACA recipients grew, the curriculum was expanded to reflect changes in the sociopolitical context. We became responsible for updating participants about the implications of immigration and education policy changes on their practice. In 2012, for example, when Arizona Governor Jan Brewer issued an executive order that denied driver's licenses to DACA beneficiaries, participants needed to become aware of how institutional practices that required a driver's license created additional barriers for DACA recipients. The ban, which was not lifted until 2015, made it difficult for DACA recipients to pursue new jobs, go to school, work, and advance their careers.

Then in 2013, the state filed a lawsuit against Maricopa Community College (MCC) for extending Arizona resident tuition to DACA recipients. Though the Superior Court affirmed DACA recipients' eligibility for resident tuition in 2015, the lawsuit delayed the opportunity for many DACA beneficiaries to attend college at an in-state tuition price. These state actions deliberately targeted DACA recipients and required participants to remain abreast of students' experiences navigating these challenges in order to attend to students' needs. The same thing applied in 2014, when President Obama announced DACA expansion and DAPA. Because these executive actions did not reach implementation due to a court injunction, the emotional turmoil resultant from the blocked opportunities required participants to be extra conscious of students' mental health needs. Providing undocumented student contact via DREAMzone enabled participants to better understand the impact of the injunction on the community. 
The slew of anti-immigrant measures impacting undocumented students' educational experiences has made the work of DREAMzone particularly relevant for higher education practice. Facilitating workshops since 2012, we have witnessed how undocu-hostile environments often shape the work of human service professionals, forcing some to perform in the shadows of the institution (Chen, 2014; Chen \& Rhoads, 2016). Some participants had been working with undocumented students privately for many years, but had not made their work public. In many cases, the ability of participants to outwardly support undocumented students was suppressed by factors including a muddled understanding of immigration issues, unclear legal and ethical restrictions, and fear that higher administration, donors, and institutional policies were not supportive of these efforts. By creating a visible support system of institutional agents, DREAMzone facilitated a space for the sharing of resources and the identification of institutional practices, student support services, and outreach initiatives necessary to systematically support undocumented students' access, persistence, and matriculation. Prior to DREAMzone, participants often felt isolated and overwhelmed in their efforts to support undocumented students. The network of institutional allies that developed ultimately enabled participants to gain support for upholding their professional responsibility to advocate with and for all students, regardless of students' immigration status.

\section{Future Directions}

The amalgamation of anti-immigrant sentiment across all levels of government makes it essential for counselors and human service professionals to engage in interventions such as DREAMzone that seek to reduce stigma and discrimination toward undocumented immigrants. However, more research is needed to fully understand the effects of DREAMzone, both cognitive and behavioral, and how institutions tangibly benefit from such interventions. Researchers should invest time in knowledge mobilization initiatives such as DREAMzone that are socially embedded and involve communities as active agents. Given the growing mistrust for public institutions in states like Arizona, participatory action research may provide opportunities to both strengthen the institution's relationship with the community and explore outcomes associated with participation in such interventions.

On campus, interventions such as DREAMzone should be followed by conscious efforts to increase the availability of visible support structures for undocumented students. Institutional missions, for example, should make clear to faculty, staff, and students that serving undocumented students' academic and social needs is part of achieving equity in higher education (Barnhardt, Phillips, Young, \& Sheets, 2016). Providing institutionalized safe spaces and identifying as a sanctuary campus, for example, would reaffirm an institution's commitment to serving undocumented students as a matter of inclusive excellence. These types of spaces are increasingly important as changes in law, policy, and popular culture threaten to impose additional barriers to the already limited access of undocumented students to in-state tuition, state-based financial aid, and college admission across states.

Within the walls of higher education, a focus should also be placed on providing undocumented students with mental health support, academic counseling, career counseling, legal aid, and financial aid resources. Counseling centers, outreach programs, resource centers, and offices for undocumented students all offer unique opportunities to provide such institutionalized support. As modeled by the Undocumented Student Program at the University of California at Berkley (Canedo Sanchez \& So, 2015), these types of spaces can support undocumented students from the point of admission all the way to graduation. Additionally, support services including work-study programs, emergency grants, 
undocumented support groups, and lending libraries would enable undocumented students to persist academically despite the barriers imposed by their undocumented status (DeAngelo, Schuster, \& Stebleton, 2016).

Interventions such as DREAMzone are investing in the personal, social, and academic development of undocumented students by transforming the ways counselors and other human service professionals think about diversity on campus. It is our hope that such efforts will continue to empower institutional agents to effectuate change on campus that is systematic and sensitive to the needs and experiences of undocumented students. Given the current administration's aggressive approach to immigration enforcement, it is possible that policies and institutional practices intended to protect undocumented students may cease to exist. In such case, programs like DREAMzone will be increasingly needed to advocate with and for undocumented students and help mediate the impact of immigration enforcement on students' educational experiences.

\section{Author Contact Information}

Correspondence regarding this article should be directed to: Jesus Cisneros, 230 Mashburn/201 Donaghey University of Central Arkansas, Conway, AR 72035

Email: jcisneros@uca.edu

Jesus Cisneros is an assistant professor of College Student Personnel Services and Administration at the University of Central Arkansas. He is also co-founder of DREAMzone, a socially embedded knowledge mobilization initiative that provides higher education professionals, school leaders, and pre-service educator training programs with awareness, knowledge, and skills for responding to the presence and needs of undocumented students.

Anna Lopez is an assistant professor in the Counseling and Educational Psychology department at New Mexico State University. Her research focuses on issues of social justice and advocacy, particularly with regard to undocumented immigrants and their families. Other research interests include multicultural/ bilingual counseling and supervision, body image, and eating disorders.

\section{References}

Barnhardt, C., Phillips, C., Young, R. L., \& Sheets, J. K. (2016). The administration of diversity and equity on campuses and its relationships to serving undocumented immigrant students. Journal of Diversity in Higher Education. Advance online publication. http://dx.doi.org/10.1037/a0040025

Bernard, W. S. (2009). Immigrants and refugees: Their similarities, differences, and needs. International Migration, 14(4), 267-280.

Blau, F. D., \& Mackie, C. (Eds.) (2016). The economic and fiscal consequences of immigration. Washington, DC: The National Academy of Sciences. 
Cadenas, G., Cisneros, J., Todd, N. R., \& Spanierman, L. B. (2016, December 15). DREAMzone: Testing two vicarious contact interventions to improve attitudes toward undocumented immigrants. Journal of Diversity in Higher Education. Advance online publication. http://dx.doi.org/10.1037/dhe0000055

Canedo Sanchez, R. E., \& So, M. L. (2015). UC Berkeley's Undocumented Student Program: Holistic strategies for undocumented student equitable success across higher education. Harvard Educational Review, 85(3), 464-479.

Cervantes, J. M., Mejia, O. L., \& Mena, A. G. (2010). Serial migration and the assessment of extreme and unusual psychological hardship with undocumented Latina/o families. Hispanic Journal of Behavioral Sciences, 32(2), 275-291.

Chávez, L. R. (1997). Shadowed lives: Undocumented immigrants in American society. Fort Worth, TX: Harcourt Brace.

Chen, A. C. (2014). Navigating institutional structures: The politics of supporting undocumented students in higher education. In J.P. Koyama \& M. Subramanian (Eds.), Education in a world of migration: implications for policy and practice. New York, NY: Routledge.

Chen, A. C., \& Rhoads, R. A. (2016). Undocumented student allies and transformative resistance: An ethnographic case study. The Review of Higher Education, 39(4), 515-542.

Contreras, F. (2009). Sin papeles y rompiendo barreras: Latino students and the challenges of persisting in college. Harvard Educational Review, 79(4). 610-631.

Corazon de Tucson. (2012, January). The corrections corporation of America: How CCA abuses prisoners, manipulates the public and destroys communities. Retrieved from http://fuerzatucson.files.wordpress.com/2012/03/corazon-cca-report.pdf

De Genova, N. P. (2002). Migrant "illegality" and deportability in everyday life. Annual Review of Anthropology, 31(1), 419-447.

DeAngelo, L., Schuster, M. T., \& Stebleton, M. J. (2016, September). California DREAMers: Activism, identity, and empowerment among undocumented college students. Journal of Diversity in Higher Education, 9(3), 216-230.

Diaz-Strong, D., Gomez, C., Luna-Duarte, M. E., \& Meiners, E. R. (2011). Purged: Undocumented students, financial aid policies, and access to higher education. Journal of Hispanic Higher Education, 10(2), 107-119.

Donato, K. M. \& Patterson, E. (2004). Women and men on the move: Undocumented border crossing. In J. Durand \& D. S. Massey (Eds.), Border: Research from the Mexican Migration Project (pp. 111-130). New York, NY: Russell Sage Foundation.

Flores, S. M. (2010). State dream acts: The effect of in-state resident tuition policies and undocumented Latino students. The Review of Higher Education 33(2), 239-283. 
Gaytan, F. X., Carhill, A., \& Suarez-Orozco, C. (2007). Understanding and responding to the needs of newcomer immigrant youth and families. The Prevention Researcher, 14(4), 10-13.

Gee, L. C., Gardner, M., \& Wiehe, M. (2016). Undocumented immigrants' state \& local tax contributions. The Institute on Taxation and Economic Policy. Retrieved from http://www.itep.org/pdf/immigration2016.pdf

Gildersleeve, R. E., Rumann, C., \& Mondragon, R. (2010). Serving undocumented students: Current law and policy. New Directions for Student Services, (131), 5-18.

Gildersleeve, R. E., \& Vigil, D. (2015). Institutionalizing support for undocumented Latino/a students in American higher education. New Directions for Higher Education, 172, 39-49.

Gonzáles, R. G. (2009). Young lives on hold: The college dreams of undocumented students. New York, NY: College Board.

Gonzáles, R. G. (2010). On the wrong side of the tracks: Understanding the effects of school structure and social capital in the educational pursuits of undocumented immigrant students. Peabody Journal of Education, 85(4), 469-485.

Gonzáles, R. G. (2011). Learning to be illegal: Undocumented youth and shifting legal contexts in the transition to adulthood. American Sociological Review, 76, 602-619.

Gonzáles, R. G., \& Chavez, L. R. (2012). "Awakening to a nightmare": Abjectivity and illegality in the lives of undocumented 1.5-generation Latino immigrants in the United States. Current Anthropology, $53,255-281$.

Gonzáles, R. G, Heredia, L. L., \& Negron-Gonzáles, G. (2015). Untangling Plyler's legacy: Undocumented students, schools, and citizenship. Harvard Educational Review, 85(3) 318-341.

Gonzáles, R. G., Suárez-Orozco, C., \& Dedios-Sanguineti, M. C. (2013). No place to belong: Contextualizing concepts of mental health among undocumented immigrant youth in the United States. American Behavioral Scientist, 57, 1174-1199.

Greenman, E., \& Hall, M. (2013). Legal status and educational transitions for Mexican and Central American immigrant youth. Social Forces, 91, 1475-1498.

Immigration Policy Center. (2011). Unauthorized immigrants pay taxes, too: Estimates of the state and local taxes paid by unauthorized immigrant households. Retrieved from https://www.americanimmigrationcouncil.org/research/unauthorized-immigrants-pay-taxestoo

Jauregui, J. A., \& Slate, J. R. (2010). Texas borderland community colleges and views regarding undocumented students: A qualitative study. Journal of College Student Retention: Research, Theory, \& Practice, 11(2), 183-210. 
Lewis, J. A., Arnold, M. S., House, R. \& Toporek, R. L. (2002). Advocacy Competencies: Task Force on Advocacy Competencies. Alexandria, VA: American Counseling Association. Retrieved from http://www.counseling.org/Content/NavigationMenu/RESOURCES/ADVOCACYCOM PETENCIES/advocacy_competencies1.pdf

Lopez, T. (2011, September). Left back: The impact of SB 1070 on Arizona's youth. Tucson, AZ: University of Arizona. Retrieved from http://www.law.arizona.edu/depts/bacon_program/pdf/Left_Back.pdf

Martinez, L. M. (2014). Dreams deferred: The impact of legal reforms on undocumented Latino youth. American Behavioral Scientist, 58(14), 1873-1890.

McGuire, S., \& Martin, K. (2007). Fractured migrant families: Paradoxes of hope and devastation. Family Community Health, 30(3), 178-188.

Menjívar, C., \& Abrego, L. J. (2012). Legal violence: Immigration law and the lives of Central American immigrants. American Journal of Sociology, 117, 1380-1421.

Menjívar, C., \& Kanstroom, D. (2014). Constructing immigrant "illegality": Critiques, experiences, and responses. New York, NY: Cambridge University Press.

National Conference of State Legislators. (2015). Undocumented student tuition: Overview. Retrieved from http://www.ncsl.org/research/education/undocumented-student-tuition-overview.aspx.

Oseguera, L., Flores, S. M., \& Burciaga, E. (2010). Documenting implementation realities: Undocumented immigrant students in California and North Carolina. Journal of College Admission, 206, 37-43.

Passel, J. S. (2003). Further demographic information relating to the DREAM Act. Retrieved from http://www.nilc.org/immlawpolicy/dream/dream_Demographics.pdf

Passel, J. S., \& Cohn, D. (2016). Overall number of United States unauthorized immigrants holds steady since 2009: Decline in share from Mexico mostly offset by growth from Asia, Central America and Sub-Saharan Africa. Retrieved from http://www.pewhispanic.org/2016/09/20/overall-numberof-u-s-unauthorized-immigrants-holds-steady-since-2009/

Passel, J. S., \& Lopez, M. H. (2012). Up to 1.7 million unauthorized immigrant youth may benefit from new deportation rules. Retrieved from http://www.pewhispanic.org/2012/08/14/up-to-1-7million-unauthorized-immigrant-youth-may-benefit-from-new-deportation-rules/

Pérez, P. A., \& Rodríguez, J. (2011). Access and opportunity for Latina/o undocumented college students: Familial and institutional support factors. Association of Mexican American Educators Journal, 5(1), 14-21.

Pérez, W. (2010). Higher education access for undocumented students: Recommendations for counseling professionals. Journal of College Admission, 206, 32-35. 
Pérez, W., \& Cortes, R. (2011). Undocumented Latino college students: Their socioemotional and academic experience. El Paso, TX: LFB Scholarly Publishing.

Pérez, W., Cortes, R., Ramos, K., \& Coronado, H. (2010). "Cursed and blessed": Examining the socioemotional and academic experiences of undocumented Latina and Latino college students. New Directions for Student Services, (131), 35-51.

Pérez, W., Espinoza, R., Ramos, K., Coronado, H. M., \& Cortes, R. (2009). Academic resilience among undocumented Latino students. Hispanic Journal of Behavioral Sciences, 31(2), 149-181.

Pew Hispanic Research Center. (2006). Modes of entry for the unauthorized migrant population: Fact sheet. Retrieved from http://www.pewhispanic.org/2006/05/22/modes-of-entry-for-theunauthorized-migrant-population/

Ratts, M. J., Singh, A. A., Nassar-McMillan, S., Butler, S. K., \& McCullough, J. R. (2015). Multicultural and Social Justice Counseling Competencies. Retrieved from http://www.multiculturalcounseling.org/index.php?option=com_content\&view=article\&id=205: amcd-endorses-multicultural-and-social-justice-counselingcompetencies\&catid=1:latest \&ltemid $=123$

Ridley, C. R., Mendoza, D. W., \& Kanitz, B. E. (1994). Multicultural training: Reexamination, operationalization, and integration. The Counseling Psychologist, 22, 227-289.

Rumbaut, R.G. (2004). Ages, life stages, and generational cohorts: Decomposing the immigrant first and second generations in the United States. International Migration Review, 38(3), 1160-1205.

Russell, A. (2011). State policies regarding undocumented college students: A narrative of unresolved issues, ongoing debate and missed opportunities. Washington, DC: American Association of State Colleges and Universities.

Sáenz, V., Aguilar Rodríguez, A., Martínez, M., \& Romo, E. (2011). The college pathways of foreign-born and native-born Latina/o college students at four-year institutions. Association of Mexican American Educators Journal. 5(1), 31-40.

Stuesse, A., \& Coleman, M. (2014). Automobility, immobility, altermobility: Surviving and resisting the intensification of immigrant policing. City \& Society, 26(1), 51-72.

Suárez-Orozco, C., Yoshikawa, H., Teranishi, R. T., \& Suarez-Orozco, M. M. (2011). Growing up in the shadows: The developmental implications of unauthorized status. Harvard Educational Review, $81(3), 438-472$.

Suárez-Orozco, C., Katsiaficas, D., Birchall, O., Alcantar, C. M., Hernandez, E., Garcia, Y., ...Teranishi, R. T. (2015). Undocumented undergraduates on college campuses: Understanding their challenges and assets and what it takes to make a undocufriendly campus. Harvard Educational Review, $85(3), 427-465$. 
Sue, D. W., Bernier, J. E., Durran, A., Feinberg, L., Pederson, P., Smith, E. J., \& Vasquez-Nuttal, E. (1982). Position paper: Cross-cultural counseling competencies. Counseling Psychologists, 10, 45-52.

Szkupinski Quiroga, S., Medina, D. M., \& Glick, J. (2014). In the belly of the beast: Effects of antiimmigration policy on Latino community members. American Behavioral Scientist, 58(13), $1723-$ 1742.

Teranishi, R. T., Suárez-Orozco, C., \& Suárez-Orozco, M. (2015). In the shadows of the ivory tower: Undocumented undergraduates and the liminal state of immigration reform. Retrieved from http://www.undocuscholars.org/undocuscholars-report.html.

Zong, J. \& Batalova, J. (2016, April 14). Frequently requested statistics on immigrants and immigration in the United States. Retrieved from http://www.migrationpolicy.org/article/frequently-requestedstatistics-immigrants-and-immigration-united-states - Unauthorized Immigrants 